\title{
PERFORMANCE OF CYLINDRICAL LEAF WETNESS DURATION SENSORS IN A TROPICAL CLIMATE CONDITION
}

\author{
Eduardo Alvarez Santos ${ }^{1}$; Paulo Cesar Sentelhas ${ }^{2 *}$; Terry James Gillespie ${ }^{1}$; Jorge Lulu ${ }^{3}$ \\ ${ }^{1}$ University of Guelph - Dept. of Land Resource Science, 50 Stone Road East - Guelph, Ontario, N1G 2W1, \\ Canada. \\ ${ }_{3}^{2}$ USP/ESALQ - Depto. de Ciências Exatas, C.P. 09 - 13.418-900 - Piracicaba, SP - Brasil. \\ ${ }^{3}$ USP/ESALQ - Programa de Pós-Graduação em Física do Ambiente Agrícola. \\ *Corresponding author <pcsentel@esalq.usp.br>
}

\begin{abstract}
Leaf wetness duration (LWD) measurements are required for disease warning in several agricultural systems, since it is an important variable for the diagnose of plant disease epidemiology. The cylindrical sensor is an inexpensive and simple electronic LWD sensor initially designed to measure this variable for onions, however some studies show that it may be helpful for standard measurements in weather stations and also for different crops. Therefore, the objective of this study was to assess their performance under tropical climate conditions, in Brazil, having as standard measurements those obtained by flat plate sensors, which have presented very good performance when compared with visual observations. Before field assessments, all LWD sensors used in our study (flat plates and cylinders) were white latex painted and submitted to a heat treatment. Laboratory tests were performed in order to determine the resistance threshold for the sensor to be considered wet and the time response of the sensors to wetness. In the field, all cylindrical sensors were initially deployed horizontally $30-\mathrm{cm}$ above a turfgrass surface in order to assess the variability among them with respect to LWD measurements. The variability among the horizontal cylindrical sensors was reduced by using a specific resistance threshold for each sensor. The mean coefficient of variation (CV) of LWD data measured by the cylindrical sensors was $9.7 \%$. After that, the cylindrical sensors were deployed at five different angles: $0^{\circ}, 15^{\circ}, 30^{\circ}, 45^{\circ}$, and $60^{\circ}$. Data of measurements made at these angles were compared with the standard measurement, obtained by flat plate sensors at the same height and installed at $45^{\circ}$. The deployment angle had no systematic effect on LWD measurements for the local tropical conditions, since the correlations between flat plate and elevated cylinder measurements were very high $\left(\mathrm{R}^{2}>0.91\right)$, which differed from the results obtained under temperate climatic conditions, where LWD measured by cylinders were two hours longer than by flat plate sensors.
\end{abstract}

Key words: deployment angle, electronic sensors, dew, rain, disease-warning systems

\section{DESEMPENHO DE SENSORES CILÍNDRICOS PARA MEDIDA DA DURAÇÃO DO PERÍODO DE MOLHAMENTO FOLIAR EM CONDIÇÕES DE CLIMA TROPICAL}

\begin{abstract}
RESUMO: Medidas da duração do período de molhamento (DPM) são necessárias para diversos sistemas de alerta fitossanitário, uma vez que a DPM é uma variável importante para a epidemiologia. O sensor cilíndrico é um sensor eletrônico barato e que pode ser facilmente produzido. Esse sensor foi inicialmente projetado para medir DPM em cebola, contudo alguns estudos indicam que ele também pode ser utilizado em estações meteorológicas e outras culturas. Portanto, o objetivo deste estudo foi avaliar o desempenho de sensores cilíndricos sob condições tropicais, no Brasil, tendo-se as medidas obtidas pelo sensor de placa como referência. Antes de serem instalados no campo, todos os sensors eletrônicos utilizados no estudo (placa e cilíndricos) foram pintados com tinta latex branca e, em seguida, submetidos a tratamento térmico. Testes de laboratório foram realizados para determinar um limiar de resistência, a partir do qual os sensores seriam considerados molhados, e o tempo de reposta dos sensores ao molhamento. No campo, todos os sensores foram inicialmente instalados na horizontal a $30 \mathrm{~cm}$ de altura sobre gramado, visando a avaliar a variabilidade entre os sensores de DPM. A variabilidade entre os sensores cilíndricos na horizontal foi reduzida com a adoção de um limiar de resistência específico para cada sensor. O coeficiente médio de variação para DPM diária medida pelos sensores cilíndricos foi igual a 9,7\%. Posteriormente, os sensores cilíndricos foram instalados
\end{abstract}


em 5 ângulos diferentes com a horizontal: $0,15,30,45$, and $60^{\circ}$. As medidas obtidas por esses sensores são comparáveis com a medida padrão, fornecida por sensores de placa instalados a $45^{\circ}$ e mesma altura. A mudança do ângulo de instação não teve efeito sistemático sobre as medidas da DPM para as condições locais, uma vez que as correlações entre as medidas dos sensores de placa e sensores cilídricos inclinados foram bastante elevadas $\left(\mathrm{R}^{2}>0,91\right)$, o que difere dos resultados obtidos em condições de clima temperado, onde a DPM medida pelo sensor cilíndrico foi duas horas mais longa do que a medida pelo sensor de placa.

Palavras-chave: ângulo de instalação, sensores eletrônicos, orvalho, chuva, sistemas de alerta

\section{INTRODUCTION}

Leaf wetness duration (LWD) is defined as the period during which rain, dew or fog droplets are retained on aerial plant surfaces at a microscopic scale (Wal, 1978). LWD and temperature are the most important environmental variables for the control of the majority of plant diseases, since they affect the infection and sporulation processes of many fungal pathogens (Vale et al., 2004). For this reason, several plant disease-warning systems are based on LWD and temperature measurements (Berton \& Melzer, 1989; Carisse \& Kushalappa, 1990; Huber \& Gillespie, 1992). However, LWD is more difficult to be measured or estimated than air temperature, since wetness varies considerably with the weather conditions and also with the type of crop, position, angle, and geometry of the leaves, and the specific location on the individual leaf (Sutton et al., 1984).

Several instruments have been developed to measure wetness duration (Gillespie \& Kidd 1978; Smith \& Gilpatrick, 1980; Weiss \& Lukens, 1981; Weiss \& Hagen, 1983; Gillespie \& Duan, 1987; Giesler et al., 1996). Gillespie \& Duan (1987) developed a low cost cylindrical sensor of easy construction. Its sensing surface faces a solid angle of $2 \pi$ radians (360 degrees), which represents better some organs, such as stems. However, some studies have shown that cylindrical sensors should be used with caution, since there is no protocol for their deploying for standard measurements (Gillespie \& Duan, 1987; Sentelhas et al., 2006). Gillespie \& Duan (1987) verified that LWD measured by cylindrical sensors vertically deployed in an onion crop was two to three hours shorter, on average, than measurements obtained by flat plate sensors. On the other hand, Sentelhas et al. (2006) used cylindrical sensors deployed horizontally to measure LWD over turfgrass and other crops in a temperate climate, and observed that the mean LWD was about two hours longer than that measured by flat plate sensors, which was adopted as standard measurement.

Considering that there is no protocol to install LWD cylindrical sensors for standard measurements, the objective of this study was to assess the perfor- mance of this kind of LWD electronic sensors under a tropical climate condition, in Brazil.

\section{MATERIAL AND METHODS}

\section{Laboratory assessment}

LWD was measured using cylindrical sensors (Weather Innovations Inc., ON, Canada) and flat plate sensors (Model 237, Campbell Sci., Logan, UT, USA) (Figure 1). The cylindrical sensor is made of an acrylic tube, $20 \mathrm{~cm}$ in length, outer $\varnothing=1.3 \mathrm{~cm}$, on which two nickel wires are rolled to obtain two parallel spirals. The distance between spirals is $1 \mathrm{~mm}$. The flat plate sensor consists of a circuit board with interlacing gold-plated copper fingers, $7.6 \mathrm{~cm}$ in length and $6.3 \mathrm{~cm}$ in width. For both sensors, the condensation on their surfaces reduces the resistance between the wires or fingers. In order to measure this resistance, a data logger was used to provide an alternating current input $(\sim 5 \mathrm{~V})$ and to record the output signal of the sensor. The use of low alternating currents in the sensor minimizes self heating and electrolytic depositions on the wires or fingers as suggested by Gillespie \& Kidd (1978)

Both cylindrical and flat plate LWD sensors were white latex painted in order to increase their sensitivity to microscopic wetness droplets as well as to simulate leaf optical proprieties, following the recommendation of Gillespie \& Kidd (1978) and Sentelhas et al. (2004a). The sensors were submitted to an oven heat treatment at $65^{\circ} \mathrm{C}$ for $12 \mathrm{~h}$ in order to remove the hygroscopic components of the paint, following the procedures proposed by Gillespie \& Duan (1987). After this, laboratory tests were performed in order to establish a threshold of resistance, expressed by the ratio between the measured voltage and the excitation voltage provided by the data logger $(\mathrm{Vs} / \mathrm{Vx})$, for which the sensors were considered initially wet. In addition, the time response of the sensors was assessed to ensure that all sensors had similar response to water deposition on their surfaces. The time response was defined as the time that a dry sensor achieved the Vs/ $\mathrm{Vx}$ value equal to $3 \times 10^{-4}$, after receiving a water droplet $(\varnothing \approx 1 \mathrm{~mm})$, which corresponds to a change 

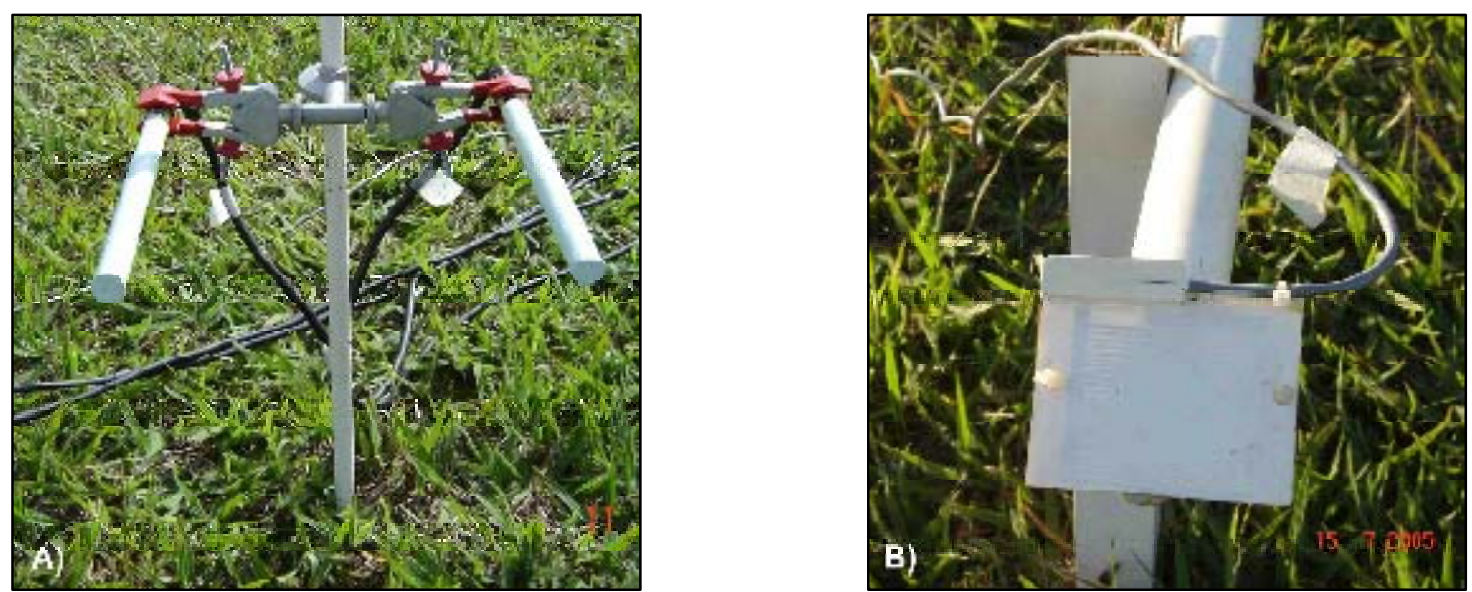

Figure 1 - Electronic leaf wetness duration (LWD) sensors: cylindrical (a) and flat plate (b).

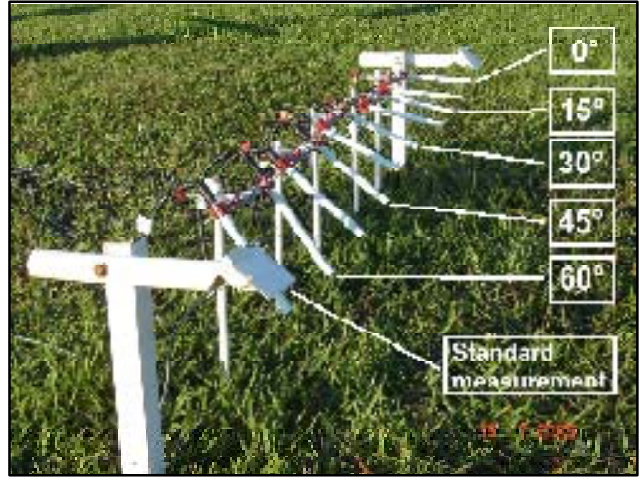

Figure 2 - Cylindrical sensors deployed at different angles to horizontal and flat plate sensors installed at $45^{\circ}$. All LWD sensors were at $30-\mathrm{cm}$ height facing south in Piracicaba, SP, Brazil.

of $1 \%$ in the signal of the dry cylindrical sensor with highest value of $\mathrm{Vs} / \mathrm{Vx}$. For the time response test, the time spent for each sensor to achieve its wetness resistance threshold (generally about $9,000 \mathrm{k} \Omega$ ) was recorded using a chronometer. This procedure was replicated four times for each sensor. The average and standard deviation of the time response were calculated for all sensors.

\section{Field assessment}

The measurements of LWD and other weather variables were performed during 93 days of the dry season (July to October 2005) in Piracicaba, São Paulo State, Brazil (2243' S, 47³0' W, 546 m). The LWD sensors were installed facing south over mowed turfgrass $(5-\mathrm{cm}$ tall $)$ at $30-\mathrm{cm}$ height in relation to soil surface, following the recommendations of Sentelhas et al. (2004b). These sensors were attached to adjustable-angle clamps allowing the angle between the sensor and the horizontal position to be changed. During an initial period of 40 days, all cylindrical sensors were maintained in the horizontal position in order to verify the variability among the LWD measurements. After this, the following deployment angles were evaluated: $0^{\circ}, 15^{\circ}, 30^{\circ}, 45^{\circ}$, and $60^{\circ}$, with two replicates for each angle (Figure 2). The height of the sensors was adjusted in order to maintain their middle point at $30 \mathrm{~cm}$ above the turfgrass surface.

Two flat plate sensors were mounted on PVC tube sections and deployed at $45^{\circ}$ to horizontal, facing south, at the $30-\mathrm{cm}$ height over the turfgrass. Sentelhas et al. (2004b) observed that LWD measurements obtained by flat plate sensors deployed in this position showed good agreement with visual observations of wetness over turfgrass, with errors smaller than $30 \mathrm{~min}$. For this reason, in this study, flat plate LWD measurements were considered standards in order to assess the cylindrical sensor's performance.

In addition to the LWD measurements, air temperature ( $\mathrm{T}$ ) and relative humidity $(\mathrm{RH})$, at $30 \mathrm{~cm}$ over turfgrass, and rainfall were also measured. T and RH were obtained by an aspirated copper-constantan thermocouple psychrometer, and rainfall was measured by a tipping bucket rain gauge (TE525WS-L, Texas Electronics, TX, USA). The sensors were connected to data loggers (CR10 and CR23X, Campbell Sci., Logan, UT, USA), programmed for readings each five seconds. Averages of air temperature, relative humidity and the signals provided by each LWD sensor; the total precipitation; as well as the histogram with the proportion of time in which each LWD sensor was wet, were recorded for 15-min intervals. LWD was totaled for 24-hour periods, starting at $12 \mathrm{~h} 15$ of day " $n$ " and finishing at $12 \mathrm{~h} 00$ of day " $\mathrm{n}+1$ ". By using the mean values of the signal recorded for each sensor during the dry period, individual thresholds for each LWD cylindrical sensor was established for field conditions. 


\section{Data analysis}

The variability among LWD measurements, obtained for the cylindrical sensor deployed horizontally, was assessed using standard deviation (SD), coefficient of variation (CV), mean absolute difference (MAD), which indicates the absolute magnitude of the mean difference, and mean difference (MD), which describes the direction of the bias, as follows:

$M A D=\frac{\sum_{i=1}^{n}\left|x c_{i}-x f_{i}\right|}{n}$

$M D=\frac{\sum_{i=1}^{n}\left(x c_{i}-x f_{i}\right)}{n}$

where: $x c_{i}$ are the LWDs measured by the cylindrical sensors, $x f_{i}$ the LWDs measured by flat plate sensors, and $\mathrm{n}$ the total number of measurements.

LWD data, provided by cylindrical sensors deployed at different angles, and the measurements of the flat plate sensors at $45^{\circ}$ were compared by regression analysis. The precision of the measurements obtained by cylindrical sensors in relation to those obtained by flat plate sensors was determined by the determination coefficient $\left(\mathrm{R}^{2}\right)$, which expresses data dispersion in relation to the simple linear regression equation, while the accuracy was determined by the agreement index (D) (Willmott et al., 1985), which expresses data dispersion in relation to 1:1 line:

$$
D=1.0-\left\{\frac{\sum\left(x c_{i}-x f_{i}\right)^{2}}{\sum\left(\left|x c_{i}-\overline{x f}\right|+\mid x f_{i}-\overline{x f}\right)^{2}}\right\}
$$

where: $x c_{i}$ is the LWD measured by the cylindrical sensors, $x f_{i}$ the LWD measured by the flat plate sensors (reference) and $\overline{x f}$ is the average LWD obtained by the flat plate sensors. D ranges from zero (no agreement or no accuracy) to one (perfect agreement or very high accuracy).
The wetness onset (time of wetness beginning) and dry-off (time of wetness ending) measured by flat plate sensors and cylindrical sensors deployed at different angles were compared using the mean difference (MD) and its standard error (SE).

\section{RESULTS AND DISCUSSION}

\section{Variability among LWD sensors}

The thresholds of resistance ratio ( Vs/Vx), obtained during the laboratory tests, were $1.2 \times 10^{-4}$ and $3 \times 10^{-4}$ for the flat plate and cylindrical sensors, respectively. Differences among individual sensors were not noticed in the laboratory tests. All LWD sensors showed short time response to the water deposition on their surface under laboratory conditions, always below $3 \mathrm{~min}$ (Table 1). The cylindrical sensors showed average time response of $73 \mathrm{~s}$. The average time response for the flat plate sensors was $12 \mathrm{~s}$.

LWD measurements obtained by cylindrical sensors over turfgrass showed higher variability than under laboratory conditions. Using different thresholds obtained from field data, it was possible to improve the cylindrical sensor measurements (Table 2). Compared to the flat plate sensors, values of MD for LWD ranged from -70.3 to $111.2 \mathrm{~min}$ when the same threshold for all sensors was used, and from -38.5 to 54.1 min when specific thresholds for each sensor were adopted. The MAD for LWD ranged from 41.1 to $112.4 \mathrm{~min}$ for sensors with the same threshold, and from 26.1 to 59.2 min when specific thresholds were used.

The increase in the variability among the cylindrical sensors when carried from the laboratory to the field can be explained by the fact that under field conditions, only a small amount of water initially condenses over the sensor. When using one wetness threshold for all sensors at wetness onset, in the absence of rain, this results in an increase of variability among the sensors. On the other hand, in the labora-

Table 1 - Mean and standard deviation (SD) of time response for two flat plate sensors (FP) and ten cylindrical sensors $(\mathrm{CYL})$ at different angles of deploy $\left(0^{\circ}, 15^{\circ}, 30^{\circ}, 45^{\circ}\right.$, and $\left.60^{\circ}\right)$ with two replicates (_1 and _2), used to measure the leaf wetness duration.

\begin{tabular}{|c|c|c|c|c|c|}
\hline Sensor & $\begin{array}{c}\text { Mean time } \\
\text { response }\end{array}$ & SD & Sensor & $\begin{array}{c}\text { Mean time } \\
\text { response }\end{array}$ & SD \\
\hline \multicolumn{4}{|c|}{ 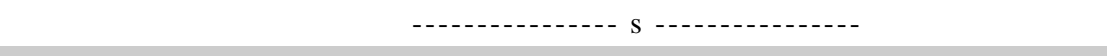 } & \multicolumn{2}{|c|}{ - } \\
\hline $\mathrm{FP}_{-} 1$ & 16 & 4 & CYL $30^{\circ} \_1$ & 36 & 3 \\
\hline FP_2 & 9 & 4 & CYL 30 ${ }^{\circ} 2$ & 184 & 40 \\
\hline $\mathrm{CYL}^{\circ}{ }_{-} 1$ & 24 & 8 & CYL $45^{\circ}{ }_{1}$ & 37 & 5 \\
\hline $\mathrm{CYL}^{\circ}{ }_{-2}$ & 119 & 34 & CYL 45﹎2 & 65 & 50 \\
\hline CYL $15^{\circ}{ }_{1}$ & 54 & 36 & CYL $60^{\circ}{ }_{1}$ & 102 & 39 \\
\hline 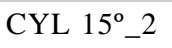 & 32 & 18 & CYL 60﹎.2 & 77 & 63 \\
\hline
\end{tabular}


Table 2 - Mean difference (MD) and mean absolute difference (MAD) between leaf wetness duration (LWD) measured by flat plate sensor and by cylindrical (CYL) sensors with different angles of deploy $\left(0^{\circ}, 15^{\circ}, 30^{\circ}, 45^{\circ}\right.$, and $\left.60^{\circ}\right)$ with two replicates (_1 and_2), using a single threshold for all cylinders and a specific threshold for each one, in Piracicaba, SP, Brazil.

\begin{tabular}{|c|c|c|c|c|}
\hline \multirow{2}{*}{$\begin{array}{l}\text { Cylindrical Sensor } \\
\text { Position }\end{array}$} & \multirow{2}{*}{$\begin{array}{c}\text { Single threshold } \\
\text { MD }\end{array}$} & \multicolumn{3}{|c|}{ Specific thresholds } \\
\hline & & MAD & MD & MAD \\
\hline & (ne-1 & - & - & - \\
\hline CYL 0 ${ }^{\circ} \_1$ & -70.3 & 81.7 & -8.9 & 43.7 \\
\hline CYL $0^{\circ} \_2$ & 74.8 & 75.0 & -38.5 & 38.5 \\
\hline CYL $15^{\circ}{ }_{-} 1$ & 111.2 & 112.4 & -8.1 & 38.7 \\
\hline CYL $15^{\circ} \_2$ & 101.4 & 103.1 & -8.9 & 32.0 \\
\hline CYL $30^{\circ} \_1$ & -39.6 & 45.5 & -0.3 & 26.1 \\
\hline CYL $45^{\circ}{ }_{-} 1$ & -6.6 & 41.1 & 54.1 & 59.2 \\
\hline CYL $45^{\circ} \_2$ & -21.6 & 48.2 & 2.7 & 52.9 \\
\hline CYL $60^{\circ} \_1$ & -29.4 & 49.0 & -27.3 & 42.8 \\
\hline CYL 60 ${ }^{\circ} \_2$ & -40.3 & 48.9 & 20.8 & 42.4 \\
\hline
\end{tabular}

tory, a larger amount of water was deposited on a single point over the sensor, and, consequently, the sensors presented a more uniform response. The sensor variability can be related to the lack of uniformity of construction and paint, which may lead to differences in the signal value and time response among the sensors. The use of specific thresholds for each sensor is a way to reduce the variability among sensor readings. Although it has some practical implications, as for example, an increase in the size of the data logger program, which can lead to errors, the use of different thresholds is advantageous, since it improves precision and accuracy of the measurements.

The CV of LWD measured by cylindrical sensors ranged from 3.2 to $33.7 \%$, with an average of $9.7 \%$, during the period that all sensors were deployed horizontally (Figure 3). The CV changed as a function of the day, with $35 \%$ of the days presenting CV above the average. Similar results were presented by Sentelhas et al. (2004a) who found CV values ranging from 0 to $31.2 \%$ and average $\mathrm{CV}=9.2 \%$ for flat plate sensors painted with white latex paint deployed at $30^{\circ}$ to horizontal and $30-\mathrm{cm}$ height in Piracicaba, $\mathrm{SP}$, Brazil. They also observed a decrease of $\mathrm{CV}$ for days when the LWD was longer. However, the CV variability does not necessarily mean that an increase of sensor variability occurred, as the $\mathrm{CV}$ has an inverse relationship with the average of the observations. For some days when the average LWD was short, the $\mathrm{CV}$ tended to be higher, even when the standard deviation was low. The variability among sensors may also be expressed by the mean absolute and mean differences between measurements provided by cylinders (Figure 4). The absolute mean difference was $29.5 \mathrm{~min}$ for onset and $13 \mathrm{~min}$ for dry-off. The mean differ-

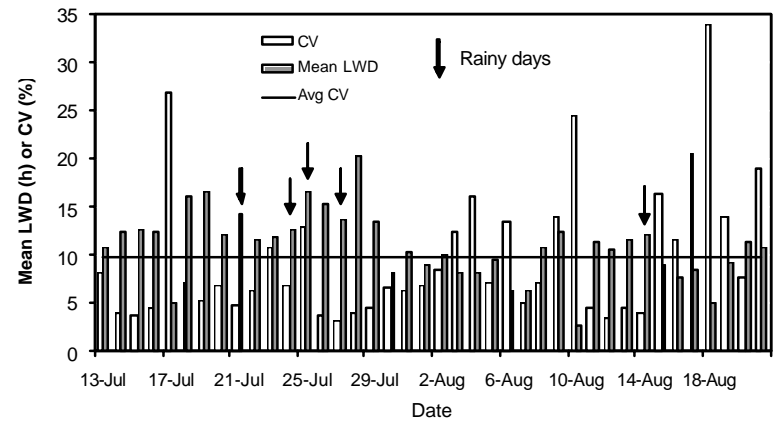

Figure 3 - Daily mean leaf wetness duration (Mean LWD - closed bars) and coefficient of variation (CV - open bars), and average (line) coefficient of variation of leaf wetness duration measurements obtained by cylindrical sensors deployed horizontally over turf grass in Piracicaba, SP, Brazil. The arrows indicate the rainy days.

ence ranged from -25.7 to $26.2 \mathrm{~min}$ for wetness onset and -10.4 and 21.9 min for wetness dry-off.

Low rates of $\mathrm{RH}$ variation before wetness onset lead to an increase of the variability among sensors (Figure 5). Although there are other variables involved in dew deposition on the sensor surface and measured RH variation rate in the free air is not exactly the same as for the air layer close to the sensor, these results show that LWD sensor performance is related to weather variables controlling the dew deposition, as well as variations in vegetative and soil moisture conditions. Weather conditions leading to rapid deposition of a larger amount of water on the sensors tend to reduce the variability among them. However, the same relationship was not observed between the dry-off and the relative humidity variation rate, indicating that other variables, such as solar radiation and wind speed, could have more influence on wetness dry-off than RH. 
Wetness Onset
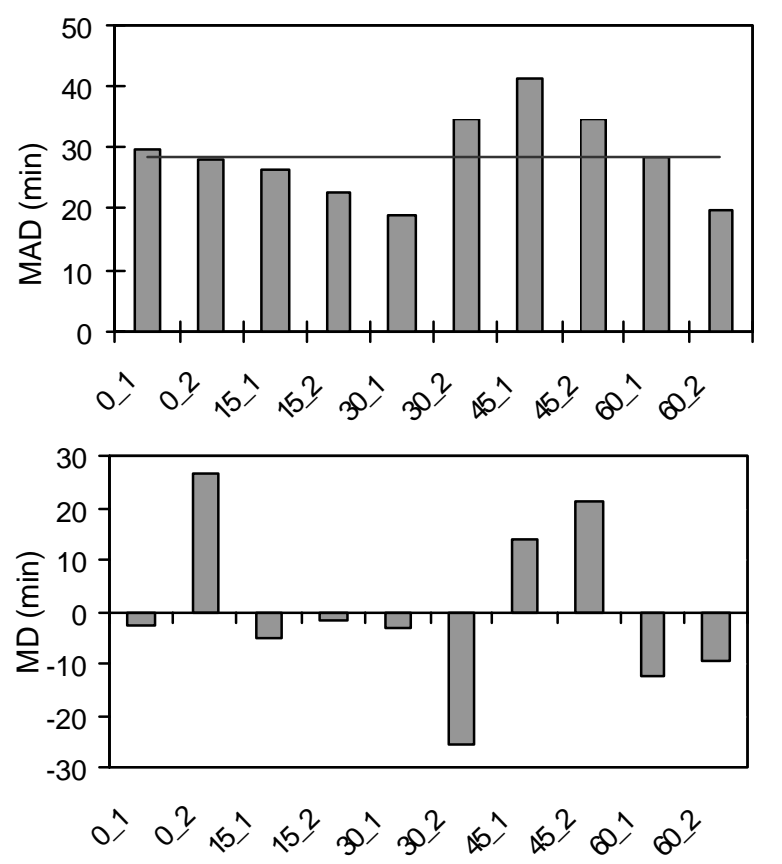

Wetness Dry-off
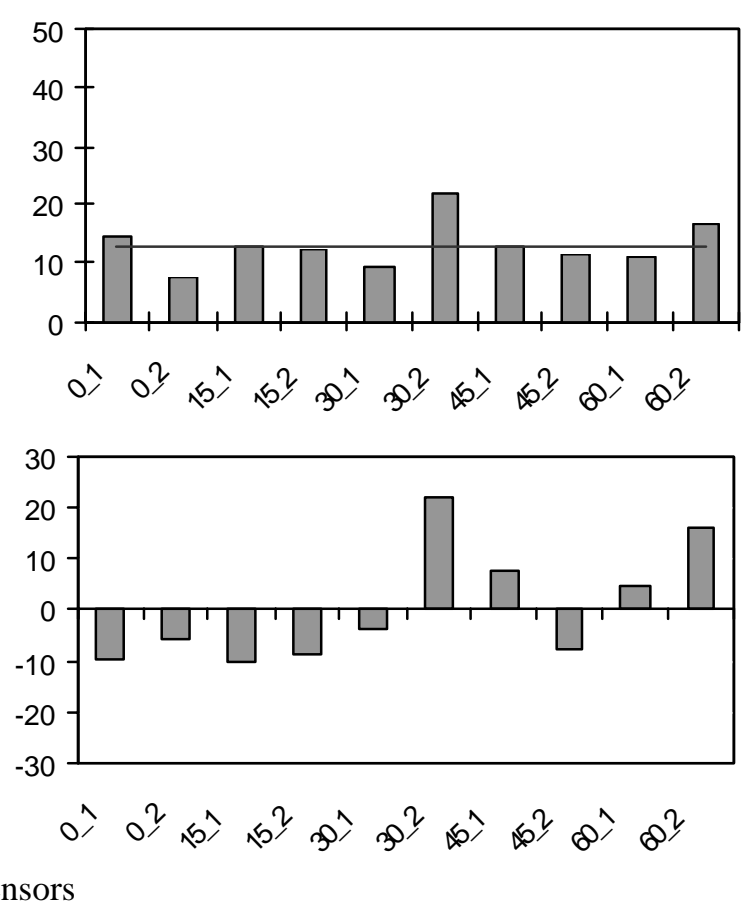

Figure 4 - Mean absolute difference (MAD) and mean difference (MD) for wetness onset and dry-off, obtained by cylindrical sensors, using the sensor average as reference, when they were horizontally positioned. The solid line represents the mean absolute difference during the period for all sensors and symbols in the $\mathrm{x}$-axis represent the sensors used in the different angles of deployment $\left(0^{\circ}, 15^{\circ}, 30^{\circ}, 45^{\circ}\right.$, and $\left.60^{\circ}\right)$ and their replicates (_1 and $\left.\_2\right)$.

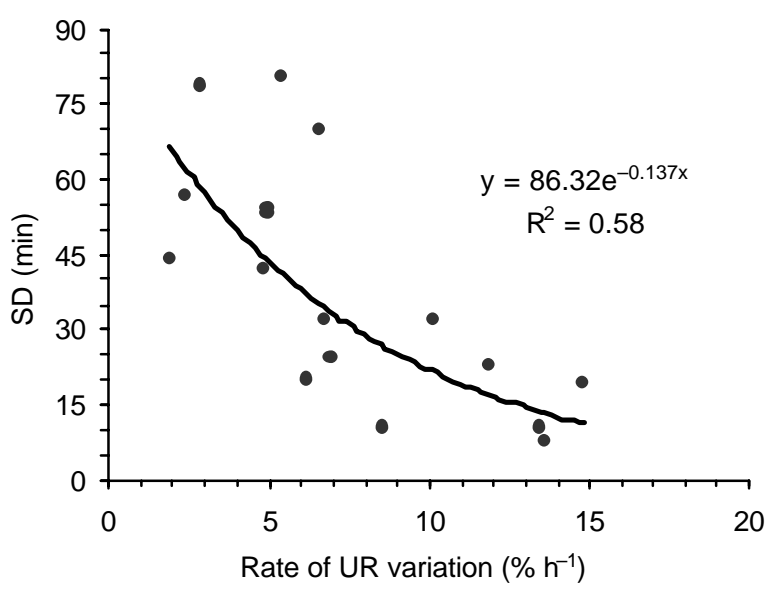

Figure 5 - Relationship between the rate of relative humidity (UR) variation in the 30 minutes before the onset and the standard deviation (SD) of the onset time indicated by the average of the cylindrical sensors, in Piracicaba, SP, Brazil.

\section{Effect of the deployment angle on LWD measure- ments by cylindrical sensors}

The difference between the mean LWD obtained by cylindrical and flat plate sensors was smaller than $1 \mathrm{~h}$ with no difference between the averages (Table 3). The variability of the measurements among the cylindrical sensors, deployed at different angles,
Table 3 - Average leaf wetness duration over mowed turfgrass $(5-\mathrm{cm}$ tall) measured by flat plate sensors, deployed at $45^{\circ}$, and cylindrical sensors, deployed at different angles to horizontal $\left(0^{\circ}, 15^{\circ}, 30^{\circ}, 45^{\circ}\right.$, and $\left.60^{\circ}\right)$, in Piracicaba, SP, Brazil.

\begin{tabular}{lcc}
\hline Sensor & Deployment angle & LWD \\
\hline \multirow{3}{*}{ Flat Plate } & & $\mathrm{h}$ \\
& $45^{\circ}$ & 9.0 \\
\hline \multirow{3}{*}{ Cylindrical } & $0^{\circ}$ & 8.6 \\
& $15^{\circ}$ & 7.8 \\
& $30^{\circ}$ & 9.0 \\
\hline Average_cylindrical & $45^{\circ}$ & 8.2 \\
\hline
\end{tabular}

was less than the mean CV $(9.7 \%)$ shown by the cylindrical sensors deployed horizontally.

The comparison between daily LWD measured by flat plate at $45^{\circ}$ and cylindrical sensors deployed at different angles to horizontal, during the 53 days of the dry season, is shown in Figure 6. The regression analysis coefficients were significant by a t-test $(p<0.05)$, showing that the intercepts were not different from zero and the slopes were not different from 

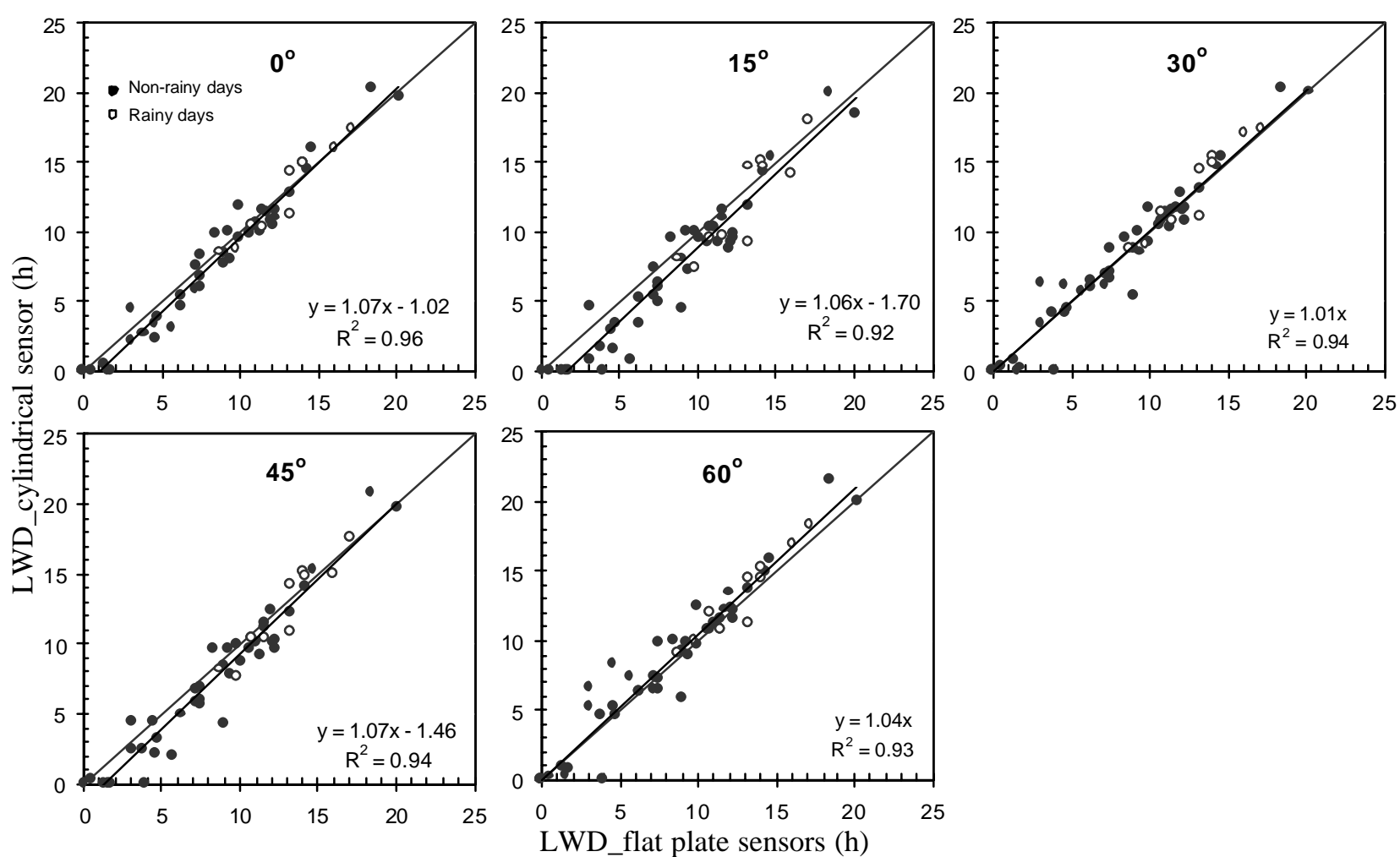

Figure 6 - Relationship between average leaf wetness duration (LWD) measured by flat plate sensors, deployed at $45^{\circ}$, and cylindrical sensors deployed at different angles to horizontal $\left(0^{\circ}, 15^{\circ}, 30^{\circ}, 45^{\circ}\right.$, and $\left.60^{\circ}\right)$, in Piracicaba, SP, Brazil.

one. Regardless of the deployment angle, daily LWD data obtained by cylindrical sensors presented high correlation with data obtained by flat plate sensors, since $\mathrm{R}^{2}$ ranged from 0.92 to 0.96 . The accuracy of the measurements, expressed by D, was also high, ranging from 0.96 to 0.99 .

Comparing flat plate sensors in the standard position (30-cm height and deployment angle of $45^{\circ}$ ) with cylindrical sensors deployed horizontally, in Elora ( $43^{\circ} 38^{\prime} \mathrm{N}, 8^{\circ} 24^{\prime} \mathrm{W}, 369$ m Altitude), ON, Canada, Sentelhas et al. (2006) noticed that LWD obtained by cylindrical sensors was systematically longer than the flat plate measurements. According to these authors, LWD overestimation may be related to the occurrence of droplets of large volume hanging along the bottom of the sensors at the end of the wetting period. Such droplets require a long time to evaporate, especially within canopies with less available energy, causing LWD overestimation. Users of these sensors in Ontario accept this overestimation as a "safety factor" when employing cylindrical sensor measurements as inputs to fungicide spray scheduling schemes.

The differences between cylindrical sensor performance in Canada and Brazil are probably related to the weather conditions of these places. During the dry season in Piracicaba, the amount of dew deposited on the sensor surface was not enough to provide a large amount of water deposition on the bottom of cylindrical sensors, but heavy dew occurred frequently at Elora. This overestimation trend was not observed in Piracicaba, even when only rainy days are considered. On these days the wetness can be provided by dew as well as rain, therefore the deposition of a larger amount of water on the sensor surfaces is expected. The larger evaporation rates occurring in the dry season in Piracicaba, compared to Elora, may explain why no LWD overestimation trend was observed within the variability among sensors.

The deployment angle had no systematic effect on the cylindrical sensor onset and dry-off (Table 4). The cylinders, except for those positioned at $60^{\circ}$, measured onset later than the flat plate sensors at $45^{\circ}$. The onset differences between the elevated and horizontally positioned cylinders were within the mean standard error, except for the cylindrical sensors at $15^{\circ}$. All cylindrical sensors dried later than flat plates; however the dry-off difference between the elevated and horizontal cylinders was within the mean standard error. In this study, observations were not taken to determine if the deployment angle affected the deposition of large droplets on the bottom of the cylindrical sensors. 
Table 4 - Differences for wetness onset and dry-off between measurements done by cylindrical and flat plate sensors (CYL -FP) and standard error of the mean (SE) for the periods in which the cylindrical sensors were deployed horizontally and at different angles of deploy $\left(0^{\circ}, 15^{\circ}, 30^{\circ}, 45^{\circ}\right.$, and $\left.60^{\circ}\right)$, in Piracicaba, SP, Brazil.

\begin{tabular}{|c|c|c|c|c|}
\hline \multirow{2}{*}{ Deployment angle } & \multicolumn{2}{|c|}{ Onset mean difference $\pm \mathrm{SE}$} & \multicolumn{2}{|c|}{ Dry-off mean difference $\pm \mathrm{SE}$} \\
\hline & Horizontal & Different angles & Horizontal & Different angles \\
\hline & - & - & ------1 & - n \\
\hline $0^{\circ}$ & $36.8 \pm 8.1$ & $37.2 \pm 8.2$ & $14.6 \pm 3.7$ & $20.7 \pm 5.9$ \\
\hline $15^{\circ}$ & $21.6 \pm 10.4$ & $58.0 \pm 11.2$ & $12.8 \pm 3.9$ & $3.8 \pm 5.7$ \\
\hline $30^{\circ}$ & $10.4 \pm 9.8$ & $11.5 \pm 9.1$ & $31.1 \pm 3.8$ & $23.0 \pm 4.7$ \\
\hline $45^{\circ}$ & $42.3 \pm 7.6$ & $43.8 \pm 9.6$ & $22.3 \pm 3.2$ & $16.0 \pm 5.8$ \\
\hline $60^{\circ}$ & $12.2 \pm 8.2$ & $-8.3 \pm 10.5$ & $31.5 \pm 3.6$ & $26.5 \pm 5.3$ \\
\hline Average & 24.6 & 28.4 & 22.5 & 18.0 \\
\hline
\end{tabular}

For the conditions in which this study was carried out, the deployment angle did not have a systematic effect on LWD measurements of cylindrical sensors. The wetness onset and dry-off were detected later by the cylindrical sensors than by the flat plates. Sentelhas et al. (2006) also observed that cylindrical sensors positioned horizontally indicated the dry-off later than flat plate sensors installed over turfgrass at $45^{\circ}$. This cylindrical sensor later dry-off may indicate that the cylindrical sensor cools down and warms up slower than the flat plate sensor, due to its higher heat capacity and different radiation geometry, resulting in a delay of the wetness onset and dry-off. However, the mean differences found for wetness onset and dry-off between cylindrical and flat plate sensors did not result in large errors in LWD measurements, as onset and dry-off differences had similar magnitude, so the onset delay was compensated by the late dry-off.

For some kinds of sensors, the deployment angle has a strong effect on LWD measurements. Lau et al. (2000) observed that non-painted flat plate sensors deployed at $30^{\circ}$ and $45^{\circ}$ responded later to the onset than sensors deployed at horizontal. Sentelhas et al. (2004b) reported longer mean LWD for painted flat plate sensors deployed at $0^{\circ}$ and $15^{\circ}$ than for sensors installed at $30^{\circ}$ and $45^{\circ}$. The cylindrical sensor seems to be less sensitive to the deployment angle than the flat plate sensors. It is probably because the cylindrical sensor has its sensitive surface exposed to 360 degrees; therefore angle variation has a smaller effect on the water accumulation on the sensor surface, especially when the amount of water condensed on the sensor surface is not enough to form large droplets along its bottom. Moreover, the variation of the sensors angle may have less influence on the energy balance of cylindrical sensors than flat plate sensors.

\section{CONCLUSIONS}

The variability among the cylindrical sensors was reduced by using resistance thresholds determined in the field to totalize the time during which the sensors were initially wet. Cylindrical sensors can be used to monitor LWD in tropical dry-season climate conditions, as their measurements presented high correlation with the reference measurements provided by flat plate sensors deployed at a standard position (30-cm height and deployment angle of $45^{\circ}$ to horizontal), with the advantage of this sensor be easily constructed. The deployment angle variation of cylindrical sensors did not have systematic effect on the LWD measurements for the local tropical conditions. However, the performance of cylindrical sensors is dependent on weather conditions, so it may not be desirable to position the sensor horizontally, since previous studies have shown that this position can lead to LWD overestimation. Based on that, it is recommended for LWD standard measurements to deploy the cylindrical sensors with an angle varying from $15^{\circ}$ to $30^{\circ}$ in relation to the horizontal plane.

\section{ACKNOWLEDGEMENTS}

This project was partially funded by CAPES and $\mathrm{CNPq}$, which granted scholarships to Eduardo A. Santos and Paulo C. Sentelhas, respectively. We are grateful to Mark Gleason and Ana C. A. Madeira for suggestions on the initial planning of this study. We also thank Francisco B. Dias and Edivaldo M. de Abreu for their assistance in the field experiment.

\section{REFERENCES}

BERTON, O.; MELZER, R. Sistema de alerta para controle da sarna da macieira. Florianópolis: EMPASC, 1989. 75p.

CARISSE, O.; KUSHALAPPA, A.C. Development of an infection model for Cercospora carotae on carrot based on temperature and leaf wetness duration. Phytopathology, v.80, p.1233-1238, 1990. 
GIESLER, L.J.; HORST, G.L.; YUEN, G.Y. A site-specific sensor for measuring leaf wetness duration within turfgrass canopies. Agriculural and Forest Meteorology, v.81, p.145-156, 1996.

GILLESPIE, T.J.; DUAN, R.X. A comparison of cylindrical and flat plate sensors. Agriculural and Forest Meteorology, v.40, p.61-70, 1987.

GILLESPIE, T.J.; KIDD, G.E. Sensing duration of moisture retention using electrical impedance grids. Canadian Journal of Plant Science, v.54, p.179-187, 1978 .

HUBER, L.; GILLESPIE, T.J. Modeling leaf wetness in relation to plant disease epidemiology. Annual Review of Phytopathology, v.30, p.553-577, 1992.

LAU, Y.F.; GLEASON, M.L.; ZRIBA, N.; TAYLOR, S. E.; HINZ, P.N. Effects of coating, deployment angle, and compass orientation on perfomance of eletronic wetness sensors during dew periods. Plant Disease, v.84, p.192-19, 2000.

SENTELHAS, P.C.; MONTEIRO, J.E.B.A.; GILLESPIE, T.J. Electronic leaf wetness duration sensor: why it should be painted. International Journal of Biometeorology, v.48, p.202-205, 2004a.

SENTELHAS, P.C.; GILlESPIE, T.J.; GLEASON, M.L.; MONTEIRO, J.E.B.A.; HELLAND, S.T. Operational exposure of leaf wetness sensors. Agricultural and Forest Meteorology, v.126, p.59-72, 2004b.

SENTELHAS, P.C.; GILLESPIE, T.J.; SANTOS, E.A. Leaf wetness duration measurement: comparison of cylindrical and flat plate sensors under different field conditions. International Journal of Biometeorology, v.51, p.265-273, 2006.
SMITH, C.A.; GILPATRICK, J.D. Geneva leaf-wetness detector. Plant Disease, v.64, p.286-288, 1980.

SUTTON, J.C.; GILLESPIE, T.J.; HILDEBRAND, P.D. Monitoring weather factors in relation to plant disease. Plant Disease, v.68, p.78-74, 1984.

VALE, F.X.R.; JESUS JUNIOR, W.C.; ZAMBOLIM, L.Z. Epidemiologia aplicada ao manejo de doenças de plantas. Belo Horizonte: Ed. Perfil, 2004. 534p.

WAL, A.F. van der Moisture as a factor in epidemiology and forecasting. In: KOSLOWSKI, T.T. (Ed.) Water deficits and plant growth: water and plant disease. New York: Academic Press, 1978. v.5, p.253-295.

WEISS, A.; LUKENS, D.L. Electronic circuit for detecting leaf wetness and comparison of two sensors. Plant Disease, v.65, p.41-43, 1981.

WEISS, A.; HAGEN, A.F. Further experiments on the measurements of leaf wetness. Agricultural Meteorology, v.29, p.207-212, 1983.

WILLMOTT, C.J.; ACKLESON, S.G.; DAVIS, R.E.; FEDDEMA, J.J.; KLINK, K.M.; LEGATES, D.R.; O’DONNELL, J.; ROWE, C.M. Statistics for the evaluation and comparison of models. Journal of Geophysical Research, v.90, p.8995-9005, 1985.

Received November 01, 2007

Accepted June 16, 2008 